\title{
STUDI POTENSI ANCAMAN PADA SITUS BENTENG GUNUNG BIRAM, ACEH BESAR, PROVINSI ACEH
}

\author{
Ambo Asse Ajis \\ Balai Pelestarian Cagar Budaya Aceh, \\ ambo.unsam@gmail.com
}

\begin{abstract}
Abstrak : Situs Benteng Gunung Biram terletak di Desa Lamtemot, Kecamatan Lembah Seulawah, Kabupaten Aceh Besar di Provinsi Aceh merupakan salah satu situs perbentengan yang dipelihara Unit Pelaksana Teknis (UPT) Balai Pelestarian Cagar Budaya Aceh.Keunikan situs ini terletak pada design arsitekturnya yang murni local genius, seperti: tidak memiliki bastion, menggunakan perekat lokal, adaptif dengan lingkungan dan fungsi yang berkelanjutan dari zaman ke zaman. Sebagai sebuah cagar budaya (CB) yang berusia lebih dari 400 Tahun, permasalahan utama yang dihadapi situs ini adalah kecenderungan ancaman terhadap kualitas fisiknyasemakin menguat. Hasil dari studi lapangan memperlihatkanada 3 (tiga) sumber ancaman yang sementara ini ditemukan, yaitu: ancaman kebencanaan, ancaman internal dan eksternal yang secara berkelanjutan memproses pelemahan strukturbenteng dari waktu ke waktu.
\end{abstract}

Kata Kunci : benteng, cagar budaya, local genius

\begin{abstract}
The Gunung Biram site, located in Desa Lamtemot, Kecamatan Seulawah Valley, Kabupaten Aceh Besar, Provinsi Aceh is one of the fortification sites maintained by the Unit Pelaksana Teknis (UPT) of Balai Pelestarian Cagar Budaya Aceh. The uniqueness of this site lies in its architectural design that is inspired purely by local genius, such as no bastion, using local adhesive, adaptive with environment and has sustainable function from time to time. As a cultural property with the age of 400 years, the main problem faced by this site is the increasing threats to itsphysical quality. Results from field studies show that there are 3 (three) threat sources that are currently being observed, namely the threat of disaster, internal and external threats that continuously impact the weakening of the fortress structure over time.
\end{abstract}

Keywords : fort, cultural heritage, local genius

\section{Latar Belakang}

Letak geografis wilayah Aceh pada gerbang Selat Melaka menjadikan Aceh sebagai daerah penting jalur perdagangan internasional pada masa lampau. Aceh menjadi salah satu tempat interaksi antar-bangsa selama berabad-abad. Bukti-bukti kejayaan peradaban tersebut masih dapat ditemukan di berbagai tempat di Aceh. Aceh Besar merupakan salah satu kabupaten yang terletak di ujung bagian barat provinsi Aceh, berbatasan dengan Selat Malaka di sisi utaranya, Samudera Hindia di sisi baratnya, Kabupaten Pidie Jaya di sebelah timur dan berbatasan Kabupaten Aceh Jaya di sebelah selatan.

Aceh Besar dikenal sebagai dengan tempat lahir beberapa kerajaan dari periode pra Islam abad ke-9 Masehi hingga lahirnya kesultanan Islam sekitar abad ke-13 Masehi dengan nama Kesultanan Lamuri. Pertama, catatan tertua tentang lokasi Aceh Besar, disebut oleh Ibn Khordadbih (pelancong Arab abad ke-9 Masehi) bahwa penduduk ujung utara Sumatera menghasilkan bambu dan kayu sepang (seupeng dalam bahasa Aceh). Akar kayu sepang ini dapat dipakai sebagai penawar racun yang mematikan. Negeri ini menghasilkan banyak pohon kapur barusyang tinggi dan menghasilkan kayu cendana (Ibrahim, 2016: 41 dalam Ajis, 2017: 3). Hall (1950) menyebutkan bahwa belum terdapat institusi pemerintahan di ujung utara Sumatera antara abad 1-4 Masehi. Penduduk di pesisir termasuk Aceh Besar, memiliki ciri menggantungkan mata pencahariannyapada laut. Mereka melakukan kontak dengan bangsa-bangsa asing di Selat Malaka. Mereka didukung oleh kekayaan alam, seperti bambu dan kayu sepang yang berkhasiat menjadi penawar racun mematikan, pohon kapur barus yang menghasilkan 
kamper. Mereka terbuka dan dapat berkomunikasi dengan bangsa asing (McKinnon 1988, 104). Selanjutnya, Mas'udi (943 M) menyebutkan bahwa lokasi ini "At a distance of about a thousand parasangs (from Serandib) are still more islands called Ramin (i.e. Ramni) well populated and governed by kings. They are full of gold mines...." (Dasguupta 1962). Artinya, pada abad ke-10 Masehi, telah ada nama negeri untuk lokasi yang telah di kunjungi Ibn Khordadbih (pelancong Arab abad ke-9 Masehi) bernama Ramin (Ramni). Karakter daerah ini merupakan daerah penghasil komoditas hutan seperti kapur barus, kayu cendana, kayu sepang, dan bambu. Ramni merupakan pulau dengan populasi yang padat dan diperintah oleh seorang raja dan memiliki beberapa lokasi tambang emas.

Catatan pelancong Arab di atas menginformasikan penduduk Ramin (Ramni) memiliki kemampuan (mahir) berdagang, hidup di pesisir, memiliki keterampilan mengolah hasil hutan (seperti kayu sepang, bambu), memiliki kemampuan membuat racun, memiliki kemampuan pengobatan akibat racun, memiliki keterampilan kelautan (membuat perahu, menangkap ikan), dan memiliki tambang emas sekaligus keterampilan dalam penambangannya. Data di atas menunjukan penduduk di kerajaan Ramin (Ramni), memiliki karakter sebagai kerajaan lokal yang dikelola dengan manajemen pembagian kerja, seperti

1. Pengelolaan dan manajemen hasil kelautan diatur oleh organisasi kelautan;

2. Pengelolaan kekayaan hutan, diatur organisasi kehutanan;

3. Pengelolaan dan manajemen perdagangan, diatur oleh organisasi perdagangan,

4. Pengelolaan dan pengaturan hasil penambangan emas diatur oleh organisasi penambangan emas. Selain itu, diperlukan ahli-ahli untuk mengolah hasil tambang emas, yang barangkali dibuat menjadi barang-barang perhiasan.

Pada tahun 1025 Masehi, Kerajaan Ramin (Ramni) diserang dan dikalahkan oleh Kerajaan Cholamandala (India). Kemudian tahun 1030 Masehi atau 5 (lima) tahun setelah penaklukan, penguasa Kerajaan Cholamandala mengganti nama kerajaan taklukannya ini dengan sebutan Ilmuridecam. Bukti arkeologis perubahan penamaan tersebut dapat ditemukan pada prasasti Tanjore yang berangka tahun 1030 Masehi.

Di awal abad ke-9 Masehi, ditemukan bacaan atas sebuah nisan kuno bertarikh 680 H / 1211 Masehi di Lamreh, Aceh Besar. Di situs tersebut ditemukan banyak sebaran nisan, gerabah, keramik dan terdapat benteng peninggalan kolonial Portugis dengan nama benteng Kuta Lubok dan benteng lokal bernama Benteng Inong Balee.

Berdasarkan kekayaan data di atas, dapatlah dijelaskan bahwa lokasi Aceh Besar telah dihuni manusia sebelum abad ke-9 Masehi dan munculnya institusi kerajaan bercorak Hindu di tempat ini sudah ada sejak abad ke-10 Masehi. Sementara itu, keberadaan Kerajaan Islam bernama Lamuri sendiri dipercaya telah ada sejak awal abad ke-13 Masehi, yang pada akhirnya melebur menjadi satu kerajaan bernama Bandar Aceh Darussalam (sering juga disebut Kesultanan Aceh Darussalam) pada awal abad ke-15 Masehi.

Selanjutnya, Benteng Gunung Biram yang menjadi objek dalam tulisan ini, berada di koordinat 5'22,07.4" N dan 95\%40'10.3'E, terletak di Desa Lamtemot, Kecamatan Lembah Seulawah, Kabupaten Aceh Besar merupakan salah satu peninggalan masa Islam, khususnya masa Kesultanan Aceh Darussalam. Referensi dari folklore yang berkembang di Aceh Besar disebutkan ketika Sultan Iskandar Muda pulang dari menggempur Portugis Martin Al Fanso de Castro dan memperoleh kemenangan, beliau singgah dan beristirahat di Ribee. Dalam satu perburuan di lembah Seulawah di sebuah bukit, telah berjumpa kembali dengan Gajah Putih Biram Sattany, yang sebelumnya pernah hilang ketika Sultan Saidil Mukammil meninggal. Bukit atau Gunung itu disebut dengan Gunung Biram (Glee Biram) di atas Lam Tamot yang terkenal sampai kini. (M. Djamill-Gajah Putih Iskandar Muda- 114).

Dari informasi dari tokoh masyarakat Desa Lamtamot yaitu Bapak M. Yusuf Gadai (67 tahun) dan M. Juned Salim (70 Tahun) menurut cerita dari orang tua beliau mengatakan bahwa di atas benteng dalam pernah didirikan bangunan yang sederhana, yang difungsikan sebagai tempat melakukan shalat (masjid), dan cerita inilah nampaknya asal muasal penyebutan situs sebagai Masjid Gunung Biram.

Pada masa dijadikan masjid, dinding bangunan masjid dibuat dari pelepah rumbia sementara atap 
bangunan dibuat dari bahan daun rumbia. Menurut informasi dari narasumber, masjid tersebut digunakan sebagai tempat melakukan ibadah sholat Jum'at masyarakat setempat, bahkan masyarakat Padang Tiji juga melakukan sholat Jum'at di Masjid Gunung Biram, dimana pada saat itu Padang Tiji masih termasuk kawasan Aceh Besar. Disekitar masjid dahulu juga didirikan kubukubu untuk tempat bermalam calon jamaah haji dari wilayah Aceh Besar yang melakukan perjalanan dengan berjalan kaki ke Pelabuhan di Kuta Raja.

Tokoh yang memprakasai pendirian masjid di atas benteng Gunung Biram adalah seorang ulama yang dikenal dengan sebutan 'Tu Gunung Biram'. Nama Gunung Biram itu sendiri berasal dari cerita tentang adanya seekor ular besar yang keluar dari sebuah lubang, dan ular besar itulah yang dikenal dengan sebutan "Biram". Sedangkan kata Seulawah menurut informasi nara sumber berasal dari kata Shalawat. Orang-orang yang pergi ke daerah Pidie pada jaman dahulu selalu singgah di Masjid Gunung Biram dan membaca Shalawat.

Ketika terjadi agresi Belanda di Aceh, Bangunan Masjid Gunung Biram menjadi salah satu sasaran penghancuran karena masjid tersebut selain berfungsi sebagai tempat shalat juga sekaligus dijadikan sebagai tempat berkumpul para pejuang dalam menyusun strategi perlawanan musuh. Penyerangan tersebut tepatnya dari Bukit Cot Nisee dan arah Lembah Seulawah kira-kira 1,5 km dari Benteng Gunung Biram, sehingga menyebabkan rusaknya sebagian dinding atas dan dinding bagian dalam. Data lain menyebutkan bahwa pada tahun 1879, Seulimem telah berhasil di duduki oleh Belanda. Pada saat itu Sultan Muhammad Daud, putra dari Sultan Mahmud Syah IV, yang masih kecil melarikan diri bersama pengiringnya ke daerah Keumala di Pidie, sementara para pengikutnya dan pejuang yang lain mundur ke Gunung Biram Lamtamot di kaki Gunung Seulawah. Mereka tidak mau menyerah biarpun mati dalam hutan asal tidak ditangkap musuh.

\section{Permasalahan}

Kabupaten Aceh Besar merupakan salah satu wilayah yang banyak ditemukan situs-situs peninggalan bersejarah. Di antara peninggalan tersebut berupa bangunan benteng-benteng kuno yang memiliki nilai penting bagi sejarah, ilmu pengetahuan, dan kebudayaan sehingga perlu untuk dilestarikan.

Namun demikian, kemegahan peradaban Aceh pada masa lampau dalam kurun waktu lebih dari satu milenium, sebagiannya meredup pada saat ini akibat berbagai faktor. Alhasil, sebagian kondisi bangunanbangunan peninggalan bersejarah pada saat ini sangat memprihatinkan. Beberapa persoalan terkait konflik pembangunan dimana banyak situs bersejarah di kawasan Banda Aceh dan Aceh pada saat ini tergusur oleh perluasan pemukiman masyarakat. Demikian juga, banyak diantaranya yang telah rusak karena pelapukan dan dimakan usia. Kerusakan bangunan-bangunan bersejarah tersebut juga diperparah oleh kondisi alam yang rentan dengan bencana. Sebagian besar lokasi bangunan-bangunan bersejarah tersebut bersinggungan dengan kawasan rawan bencana, seperti jalur sesar aktif, lereng gunung api aktif, jalur sungai, dan pantai yang berisiko dilanda bencana gempa bumi, letusan gunung api, banjir, dan tsunami.

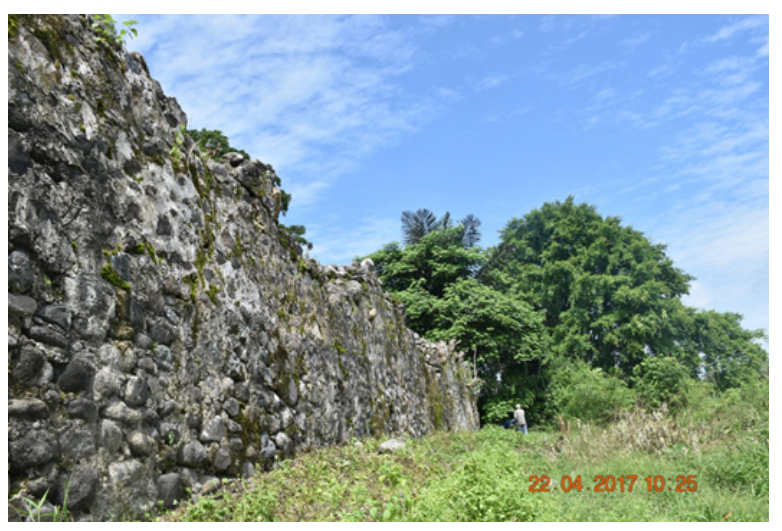

Gambar 1. Benteng Gunung Biram sisi utara

BPCB Aceh, 2017. Laporan Studi Penyelamatan Situs Benteng Gunung Biram Tahun 2017. Balai Pelestarian Cagar Budaya Aceh. Tidak dipublikasikan

Salah satu cagar budaya yang memiliki tingkat kerawanan bencana yang tinggi adalah Situs Benteng Gunung Biram. Secara geologis, posisi Desa Lamtamot tepat berada di jalur patahan aktif the Great Sumatran Fault (GSF), yaitu patahan yang aktif dan sangat panjang, membentang dari Lampung sampai ke Laut Andaman, sehingga dikenal sebagai GreatSumatranFault. Atas dasar kondisi ini, penulis merumuskan permasalahan bahwa diperlukan kesamaan pemahaman dan kesadaran atas berbagai potensi ancaman yang dihadapi oleh Benteng Gunung Biram. Kesadaran atas ancaman ini diharapkan mendorong lahirnya upaya-upaya penyelamatan yang 
lebih sistematis dimasa depan baik fisik maupun data.

\section{Metode}

Data yang digunakan pada tulisan ini bersumber dari hasil observasi lapangan dan kajian kepustakaan. Penulisannya menggunakan pendekatan induktif, dimana data-data yang sangat beragam hasil studi lapangan dan kepustakaan disusun untuk menarik kesimpulan. Teknik analisis datanya bersifat deskriptif-kualitatif.

\section{Data}

Secara umum, wilayah Aceh Besar merupakan bagian paling selatan yang dilalui oleh Jalur Patahan Sumatra di daratan Pulau Sumatera. Terdapat dua segmen patahan yang melewati wilayah Aceh Besar, yaitu Segmen Aceh pada bagian barat dan Segmen Seulimuem pada bagian timur. Desa Lamtamot merupakan salah satu wilayah yang dilalui oleh Patahan Sumatera Segmen Seulimuem. Hasil pengamatan lain terhadap kondisi fisik benteng juga ditemukan adanya ancaman internal dan eksternal yang aktif, terus menerus, mendorong pelemahan pada ikatan struktur benteng sehingga menyebabkan kerusakan struktural dalam bentuk perusakan fisik.

\section{Tabel Hasil Pengukuran Benteng Gunung Biram}

\begin{tabular}{l|cc|}
\multicolumn{1}{c}{ Variabel pengukuran } & Dinding luar & Dinding dalam \\
\hline Panjang (bagian bawah) & $28.20 \mathrm{~m}$ & $17.9 \mathrm{~m}$ \\
Lebar (bagian atas) & $28.20 \mathrm{~m}$ & $18.1 \mathrm{~m}$ \\
Panjang (bagian atas) & $27.7 \mathrm{~m}$ & \\
Lebar (bagian atas) & $27.7 \mathrm{~m}$ & \\
Tinggi (dari muka tanah) & $3.6 \mathrm{~m}$ & $0.90 \mathrm{~m}$ \\
Tinggi (dari muka lantai) & & $0.90 \mathrm{~m}$ \\
Ketebala (atas) & $1.3 \mathrm{~m}$ & \\
Lebar selasar utara & $2.3 \mathrm{~m}$ & \\
Lebar selasar timur & $2.2 \mathrm{~m}$ & \\
Lebar selasar selatan & $4.5 \mathrm{~m}$ & \\
Lebar selasar barat & $2.2 \mathrm{~m}$ &
\end{tabular}

Laporan Geofisika Situs Benteng Gunung Biram Tahun 2017. Tidak dipublikasikan

Berdasarkan hasil kajian lapangan dan kepustakaan diperoleh fakta, sumber ancaman yang signifikan terhadap situs Benteng Gunung Biram, antara lain: a) ancamanan geologis dimana situs terletak di atas garis patahan segmen seulimum, b) ancaman internal, dan c) ancaman eksternal.

\section{a. Ancaman Geologis}

Situs purbakala Benteng Gunung Biram terletak persis pada garis patahan Segmen Seulimuem di bagian selatan Gunung Api Seulawah Agam. Keberadaan benteng yang bersisian langsung dengan jalur Segmen Seulimuem tersebut merupakan satu ancaman tersendiri terhadap kelestarian bangunan, mengingat Segmen Seulimuem merupakan salah satu segmen Patahan Sumatera yang masih aktif. Keaktifan suatu patahan dapat dipelajari dari aktifitas gempa bumi.

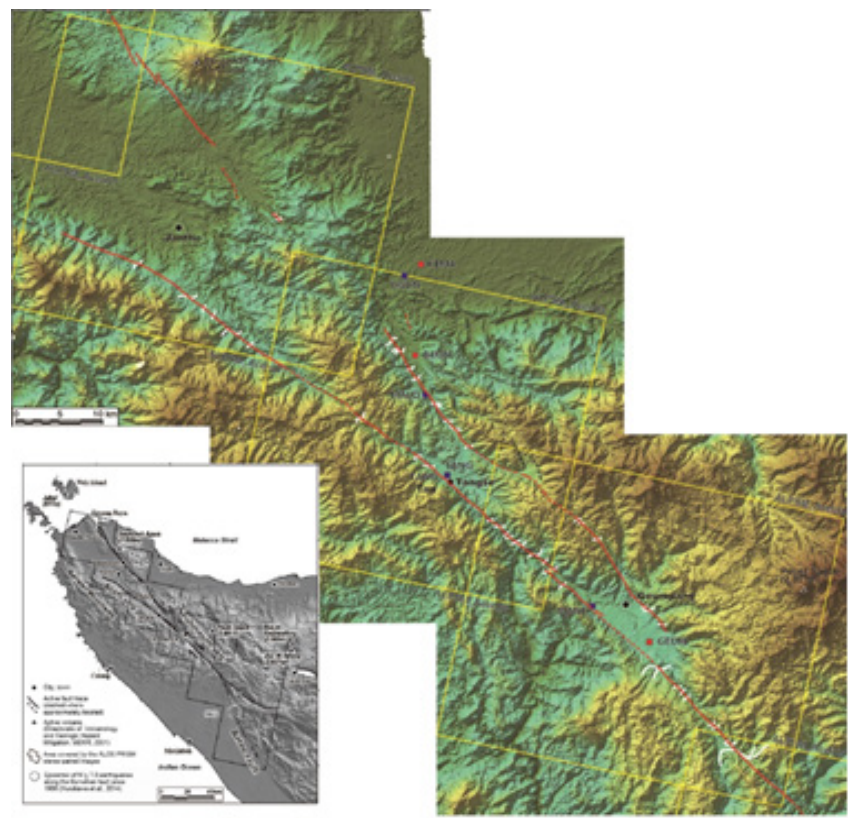

Gambar 2. Jalur Patahan Sumatera bagian utara berdasarkan interpretasi citra ALOS PRISM (Tabei, et al., 2014). Benteng Gunung Biram berada sebelah selatan Gunung Api Seulawah Agam pada bagian utara peta.

Sepanjang jalur Patahan Sumatera ini telah mengalami sejarah kegempaan yang cukup banyak, terutama di bagian Selatan Sumatera. Namun demikian bagian utara dari Patahan Sumatera belum pernah menunjukkan aktivitas seismik yang signifikan dalam jangka lebih dari 170 tahun (Bellier, et al., 1997).Bagian utara Patahan Sumatera secara terus-menerus bergerak sekitar $34 \mathrm{~mm} /$ tahun (Natawidjaja \& Sieh, 1994). Ini berarti gerakan tersebut secara kontinu menyimpan energi yang belum pernah dilepaskan (berupa kejadian gempa bumi) dalam waktu yang relatif lama (Sieh \& Natawidjaja, 2000). Berdasarkan hasil penelitian (Ito, et al., 2016) akibat kekosongan aktivitas seismik tersebut, wilayah Aceh berpotensi mengalami gempa bumi di atas magnitude 7 jika energi yang tersimpan pada lempeng Patahan Sumatera tidak dilepaskan. Kekosongan gempa bumi dalam kurun waktu yang sangat panjang tersebut merupakan ancaman yang serius bagi wilayah Aceh, mengingat gempa yang bersumber di daratan meskipun 
magnitude-nya kecil ancamannya terhadap infrastruktur dan jiwa manusia sangat fatal.

Indikasi bahwa bangunan purbakala Benteng Gunung Biram terletak pada jalur patahan Sumatera dijelaskan pada bagian berikut ini. Pada sisi barat Benteng Gunung Biram terdapat jurang tegak dengan ketinggian sekitar $7 \mathrm{~m}$ yang memisahkan antara dataran rendah pada bagian barat dan dataran tinggi pada bagian timur. Benteng Gunung Biram dibangun pada bagian dataran tinggi, yaitu persis bersisian dengan dinding vertikal jurang tersebut. Untuk sebuah bangunan yang berfungsi sebagai benteng pertahanan perang, posisi ketinggian ini sangat strategis sebagai lokasi pemantauan. Keberadaan tebing alam vertikal dan lurus sepanjang hampir $1 \mathrm{~km}$ dalam arah barat laut - tenggara tersebut dapat diinterpretasikan sebagai bagian dari jalur Segmen Seulimuem (Gambar 3). Tebing tersebut merupakan salah satu bentuk dinding patahan (faultscarp) yang terbentuk oleh aktivitas kegempaan pada masa lampau.

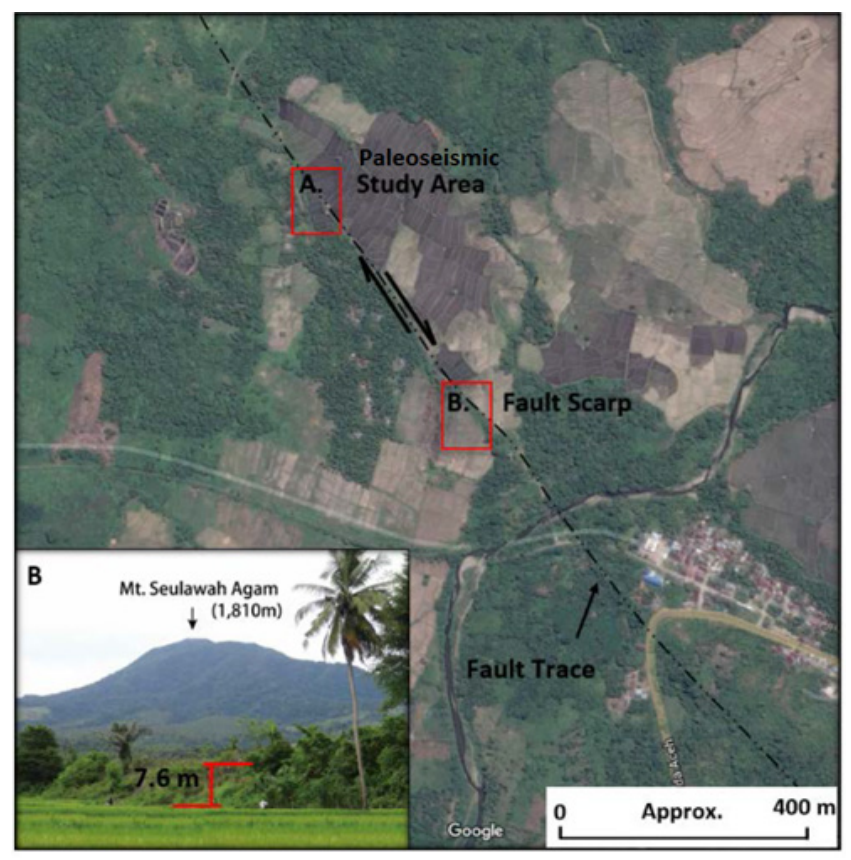

Gambar 3. Indikasi jalur patahan Sumatera berupa faultscarp, faulttrace, dan hasil kajian paleosesimik di Desa Lamtamot. Benteng Gunong Biram berada di atas faultscarp (B). Dan Gunung Api Selawah Agam berada di sebelah utara.

Selain itu, di sebelah barat laut lokasi Benteng Gunong Biram juga dapat dilihat adanya bentuk alam berupa teras pada salah satu sisi lereng Gunung Api
Seulawah Agam (Gambar 4.2 B Inzet). Pada bagian selatan Benteng Gunong Biram terdapat singkapan berupa faulttrace. Kegiatan eskavasi dan pengukuran metode geofisika dekat permukaan yang dilakukan pada bagian barat laut (Gambar $2 \mathrm{~A}$ ), sekitar $1 \mathrm{~km}$ dari bangunan benteng juga mengindikasikan adanya rekaman aktifitas kegempaan purba pada Segmen Seulimuem ini (Ismail, et al., 2017).

Sekitar Benteng Gunong Biram umumnya didominasi oleh tanah aluvial yang terdiri dari lempung, pasir dan kerikil. Sekitar lokasi juga terdapat batuan beku vulkanik hasil aktivitas gunung api pada masa lampau. Sebelah barat dan utara benteng merupakan areal persawahan. Sebelah timur benteng terdapat alur sungai kecil dan selatan benteng merupakan areal pemakaman dan dilintasi sungai besar di bawahnya. Material bangunan benteng umumnya tersusun dari kerikil yang kemungkinan besar berasal dari sungai tersebut. Namun demikian, pada bangunan benteng juga ditemukan batuan gunung api dan batu kapur sebagai pengikat matriks.

\section{b. Ancaman internal}

Kerusakan struktural pada fisik bangunan Benteng Biram terjadi pada semua komponen, yaitu: dinding, pondasi, lingkungan mikro dan makro. Persoalan yang dialami pada dinding benteng Biram, antara lain: hidupnya tanaman tingkat rendah atau lumut yang melemehkan ikatan perekat pada dinding dengan cara mengubah spesi asli (semen peng ikat) menjadi terurai hingga menjadi tanah; tumbuhnya tanaman kayu pada selasela batuan penyusun benteng yang menyebakan rekahan hingga di level ekstrim menyebakan lunaknya sambungan antar batu. Akibatnya, dinding menjadi keropos sehingga menyebabkan longsoran; semakin menuanya spesi asli (semen pengikat) antar batuan sehingga memperlemah soliditas rekatan yang berdampak sistemik pada kekuatan menghadapi tekanan dan pengaruh eksternal, seperti rentang pada getaran, terintrusi akar tanaman, pelabupakan akibat hujan, rekanan akibat tekanan panas.

Pondasi benteng juga mengalami persoalan akibat keletakan benteng sendiri berada di atas jalur patahan. Kerentanan dari getaran gempa bumi meski skala yang lebih kecil, bisa menyebabkan perubahan pada struktur pondasi yang berakibat pada dinding benteng di atasnya.

Pengaruh lingkungan mikro terhadap Benteng 
Gunung Biram meliputi iklim (suhu udara, kelembaban udara, curah hujan, angin, embun) dan kehidupan mikro organisme yang menyebabkan kerentanan pada fisik benteng. Dalam hal ini pengaruh iklim diawali oleh pengaruh langsung cuaca terutama radiasi dan suhu terhadap fotosintesis, respirasi, transpirasi dan prosesproses metabolisme di dalam sel organ tanaman yang ada di dalam dan di luar Benteng Biram. Benteng Gunung Biram berada di di bawah kaki Gunung Selawah sisi Selatan yang pada waktu malam hari suhu cukup rendah dan di siang hari suhu terbilang panas. Kekuatan pondasi, dinding, tumbuhnya tanaman rumput hingga semak belukar sangat dipengaruhi rotasi musim khususnya musim kering terjadi pada bulan Maret-Agustus dan musim hujan terjadi antara bulan September-Ferbruari (Tim melakukan kajian pada bulan April Tahun 2017 dengan kondisi cuaca lebih banyak keringnya dan diselingi dengan cuaca hujan yang normal). Dengan kata lain, akibat terpaan iklim yang terus berganti, tentu saja mempengaruhi kondisi fisik Benteng Gunung Biram, apalagi jika mengingat sejarah benteng ini sendiri telah berusialebih dari 400 tahun lalu.

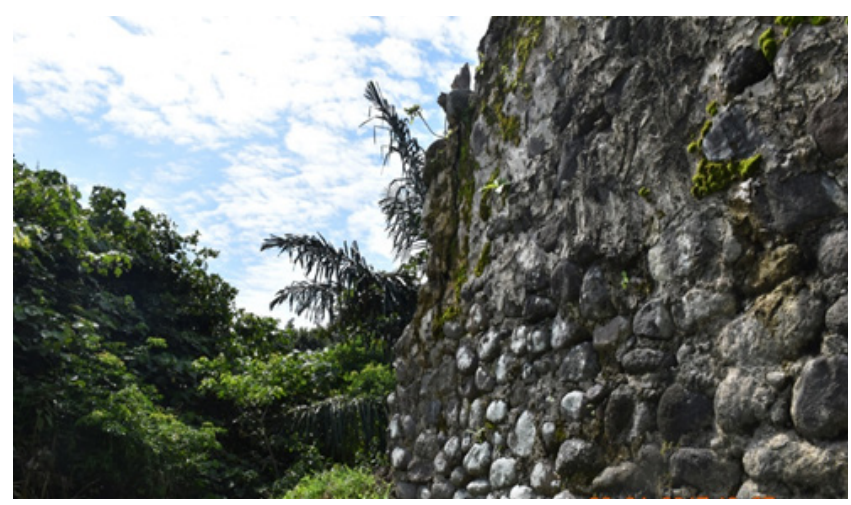

Gambar 4. Lumut yang hidup melekat di dinding Benteng Gunung biram

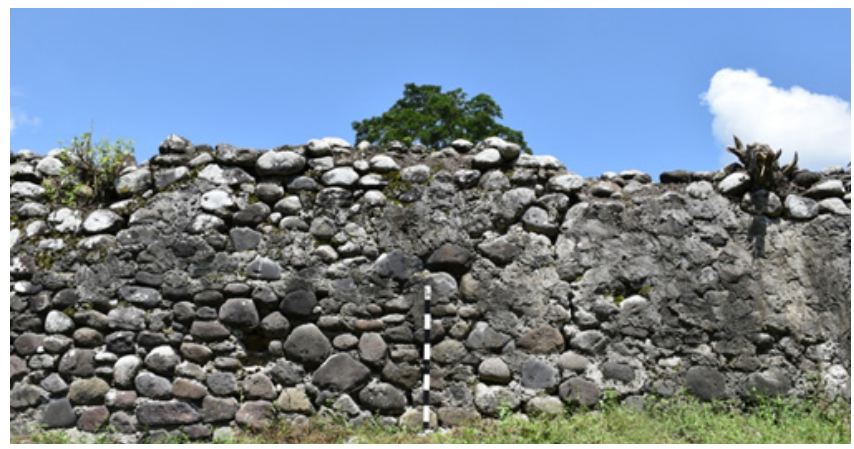

Gambar 5. Kayu mati di celah struktur benteng Gunung Gunung Biram

\section{c. Ancaman eksternal}

Lingkungan makro juga sangat memberi pengaruh pada daya tahan benteng Gunung Biram. Lingkungan makro diartikan dampak dariaktivitas manusia yang memberi pengauh signifikan pada kelestarian cagar budaya ini. Hasil pengamatan dilapangan menunjukan bahwa sisi utara dan barat Benteng Gunung Biram dsejak lama telah difungsikan sebagai jalan gampong. Dari pengamatan atas penggunaan jalan gampong ini diketahui jenis kendaraan yang melaluinya dari truk roda 4 (empat) hingga sepeda dayung.

Pengaruh siginifikan terjadi pada penggunaan truk khususnya dengan muatan kayu akibat aktivitas loging tahun 2006-2009 lalu di tempat ini. Tidak kurang dari 3-4 truk setiap harinya truk keluar dengan muatan kayu antara 4-6 ton. Dampak yang terjadi pada dinding benteng sisi utara tidak begitu signifikan mengingat jarak antara jalan raya sekitar $5 \mathrm{~m}$. Tetapi berbeda dengan dinding benteng sisi Barat yang hanya berjarak 2-3 m dari jalan menunjukan faktar terjadi rekahan-rekahan dan guguran batu pada dinding yang bisa terlihat. Pada saat ini, lingkungan Benteng Biram, belum dilakukan penataan. Meskipun ada juru pelihara yang ditunjuk memeliharanya, namun diperulakan pengelolaan ruang yang lebih khusus dalam mencegah penggunaaan lahan situs. Di sisi selatan, terdapat pemakaman yang dikhawatirkan dikemudian hari akan diisi oleh pemakaman baru. Selain itu, perlunya memikirkan perubahan areal jalan gampong mengingat dampak getaran akibat penggunaaan truk yang bisa secara permanen menyebabkan kerusakan, perlu dibicarakan dalam rangka penyelamatannya

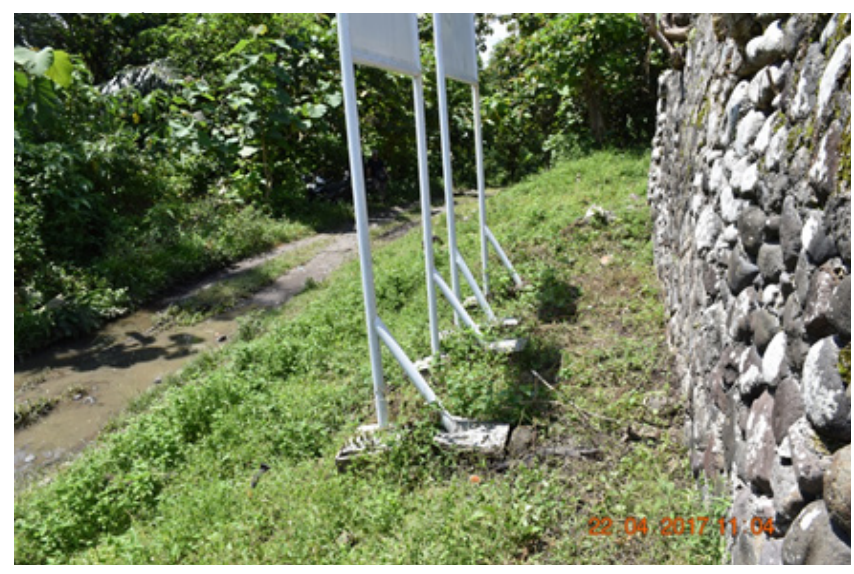

Gambar 6. Letak dinding benteng sebelah timur yang berdampingan dengan jalan desa 


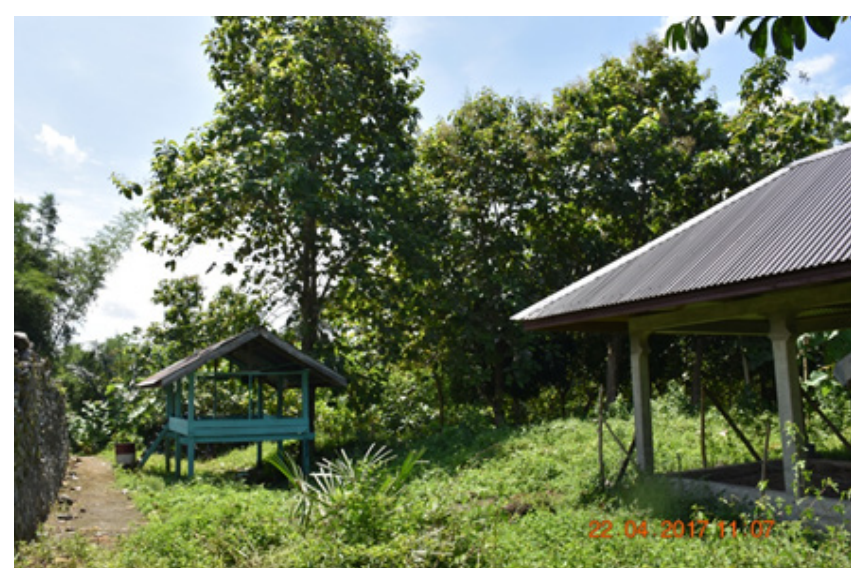

Gambar 7. Kompleks pemakaman di dinding benteng sebelah selatan

\section{Analisis}

Data yang disajikan di atas, menjelaskan betapa tingginya ancaman yang dihadapi Situs Benteng Gunung Biram baik secara mikro dan makro. Namun demikian, sampai saat ini belum ada satu materi yang disiapkan dalam bentuk road map penyelamatan, khususnya jika terjadi kondisi paling ekstrim, yakni gempa bumi yang menghancurkan Benteng Gunung Biran.

Potensi kehancuran akibat gempa adalah ancaman terbesar situs dan dibutuhkan tindakan penyelamatan ekstra besar untuk menyelamatkan data yang dimiliki Situs Benteng Gunung Biram. Beberapa bentuk penyelamatan yang diusulkan antara lain:

\section{Penyelamatan Fisik}

Penyelamatan fisik yang dimaksud berbentuk penyelamatan komponen-komponen penting dengan cara membuat duplikat baik sebagian maupun keseluruhan Benteng Gunung Biram dengan ukuran yang sebenarnya atau skala 1:1.

\section{Penyelamatan data}

Penyelamatan data dilakukan dengan melakukan perekaman data arkeologis berbasis teknologi. Beberapa model perekaman data arkeologi yang bisa dilakukan, seperti: Pembuatan sistem informasi situs yang merekam seluruh data arkeologis benteng sebelum terkena bencana, pengunaan teknologi geofisika sebagai cara mendapatkan data yang ada di dalam tanah, penggunaan teknologi drone untuk mendapatkan data eksisting kondisi situs yang dilihat dari udara, menggiatkan kegiatan survei dan ekskavasi untuk menambah data base yang akan diinput pada sisntem informasi situs dan berbagai kegiatan lainnya.;
Kedua kegiatan penyelamatan di atas merupakan tuntutan utama dalam menjaga ingatan kita terhadap Benteng Gunung Biram. Kedudukan benteng ini tidak hanya penting bagi Aceh besar atau Aceh saja, tetapi Benteng Gunung Biram merupakan satu dari sekian banyak representasi heroisme penduduk nusantara Indonesia dalam menjaga kedaulatan bangsa. Nilai penting heroisme tersebut masih kuat dalam ingatan sejarah Aceh hari ini. Bagi indonesia, Benteng Gunung Biram merupakan representasi kecerdasan manusia Indonesia yang mampu mendirikan benteng-benteng pertahanan.

Nilai penting pendidikan situs ini terletak pada sejarahnya yang berperan dalam mendukung perjuangan Sultan Iskandar Muda ketika melawan Portugis yang saat itu bermarkan di Benteng Portugis yang saat ini disebut Benteng Kuta Lubok. Di benteng inilah, Sultan Iskandar Muda melatih pasukannya, mempersiapkan perbekalan dan segala sesuatunya ketika menggempur penjajah Portugis ketika itu.

Nilaipenting pengetahuan terlihat dari kemampuan anak bangsa dari Kesultanan Aceh mendirikan bentengbentengnya sendiri sebagai bagian dari mempertahankan kedaulatan wilayah sekaligus mengatur pelayan publik di wilayah-wilayah yang dikuasainya. Benteng disusun dibuat tidak memiliki bastion, berbentuk persegi empat dengan mennggunakan batu sungai direkatkan dengan semen yang dibuat sendiri oleh ahli-ahli bangunan Kesultanan Aceh.

Berbagai nilai penting di atas menunjukan bahwa benteng Gunung Biram sangat layak diselamatkan baik fisik dan datanya. Dengan data arkeologi tersebut, berbagai stakholeder yang berkepentingan bisa mengakses dan menggunaan data-data arkeologi ini untuk berbagi kepentingan.

\section{Penutup}

Tantangan penyelamatan Situs Cagar Budaya Benteng Biram yang terletak di jalur patahan sesar membutuhkan penanganan khusus. Demikian juga kondisi fisik benteng yang semakin rentan oleh tekanan lingkungan mikro dan makro menyebabkan impresi yang berkesinambungan menyebabkan struktur benteng lebih cepat mengalami pengoroposan sebagaimana yang terlihat pada pondasi dan dinding.

Tekanan secara berkala di atas menjadi tantangan utama dalam upaya penyelamatan pada Situs Benteng 
Gunung Biram ini. Untuk itu, diperlukan penanganan holistik sehingga ruang penyelamatan memberi dampak mengatasi keseluruhan aspek persoalan.

Terkait dengan hal ini, penulis merekomendasikan model penyelamatan yang terpikirkan, antara lain:

\section{Penyelamatan Mikro}

Model penataan lingkungan ruang benteng baik di lingkungan mikro dan makro melalui kegiatan deliniasi dan zonasi, penambahan pelindung dalam bentuk naungan pada seluruh areal fisik benteng sebagaimana fungsi kondisi sebelumnya; dan kegiatan konservasi pada struktur benteng dengan fokus pada penguatan pengikat.

2. Penyelamatan makro

Penyelamatan makro benteng Gunugn Biram dengan mengintensifkan perekmana data dan pembuatan duplikat sehingga ketika patahan geoligis bekerja dan menghancurkan benteng, kita telah memiliki data utuh baik dokumentasi fisik struktur benteng maupun data tiga (3) dimensi struktur benteng maupun lingkungannya.

Pemikiran ini tentu memerlukan pertimbangan teknis.Namun, dapat disampaikan dengan melakukan deliniasi dan zonasi maka penyelamatan atas gangguan makro, khususnya ketika bersentuhan dengan penggunaan ruang oleh masyarakat akan bisa dinetralisir.

Demikianjuga pembuatan naungan yang melebihi badan struktur benteng akan mengamankan fisik struktur benteng itu sendiri dari percepatan kerusakan. Ini penting mengingat bagian dalam struktur benteng Gunung Biram ternyata tidak memiliki sistem drainase. Selama ini, air yang berada di bagian dalam benteng bebas mengintrusi seluruh celah-celahbatuan benteng yang memnjadi salah satu faktor impresif mendorong pelemahan, pelapukan, dan runtuhan. Jika naungan bisa dibuat maka tindakan konservasi dapat dilakukan dengan baik dan hasil yang terbaik karena pengendalian air, suhu tanah dan batuan sudah bisa dikendalikan. Hal yang sama pada tumbuhan lumut akan bisa dihentikan secara permanen. Sebagai penutup, upaya penyelamatan data dengan teknologi tiga dimensi akan sangat membantu proses penyalamatan jika tiba-tiba terjadi bencana gempa bumi pada sesar di bawah benteng yang menyebabkan kerusakan parah.

\section{Daftar Pustaka}

Ajis, Ambo Asse., 2017. Ramni-Ilamuridesam: Kerajaan Aceh Pra Samudra Pasai. Berkala Arkeologi Sangkhakala Nomor 2 dan Volume 20 jurnal. Medan: Balar Sumatera Utara.

2017. Kamper sebagai Cagar Budaya Warisan Dunia. Sebuah Pemikiran Awal. Majalah Kebudayaan Kemendikbud, Volume 12, No.2. Jakarta: Kementerian Pendidikan dan Kebudayaan Republik Indonesia

Anghel, S. \& Brustur, T., 2007. Geophysical Methods Used in the Archaeological Studies of the Ancient Town of "Argamum". GEO-ECOMARINA, Volume 13, pp. 97 - 100.

Bellier, O. et al., 1997. Paleoseismicity and seismic hazard along the Great Sumatran Fault (Indonesia). Journal of Geodynamics, Volume 24, pp. 169 $-183$.

Blakely, R. J., 1995. Potential Theory in Gravity and Magnetic Applications. First penyunt. Cambridge: Cambridge University Press.

Guillot, Dkk. 1998. Lobu Tua Sejarah Awal Barus. Yayasan Obor, Jakarta

Hall, DGE., 1950. Sejarah Asia Tenggara. Usaha Nasional, Surabaya

Ibrahim, dkk. 2016. Laporan Zonasi Kawasan Cagar Budaya Lamuri, Universitas

Syiah Kuala, Banda Aceh

McKinnon, E. Edwards, 2006. Beyond Serandib: A Note on Lambri at the

Northern Tip of Aceh.

Pradjoko, Didik., dan Utomo, Bambang Budi., 2013. Atlas Pelabuhan-Pelabuhan Bersejarah Indonesia. Jakarta: Direktorat Sejarah dan Nilai Budaya, Direktorat Jenderal Kebudayaan, Kementerian Pendidikan dan Kebudayaan Republik Indonesia

Perret, dkk. 2015. Barus Negeri Kamper. Sejarah Abad ke-12 hingga 
Pertengahan Abad ke-17. PT. Gramedia, Jakarta

Pradjoko, Didik dan Utomo, Bambang., 2013. Atlas Pelabuhan-Pelabuhan

Bersejarah Indonesia.Dirketorat jenderal Kebudayaan.

Suhadi, Machi., 2012. Kerajaan Panai. Indonesia Dalam Arus Sejarah,

PT. Ichtiar Baru Van Hoeve, Jakarta

Said, Mohammad, 1984. Aceh Sepanjang Abad Jilid I. Waspada Medan, Medan

Subbarayalu, Y., 2015. Prasasti Perkumpulan Pedagang Tamil di Neusu

dalam buku Barus Negeri Kamper, Sejarah Abad ke-12 hingga pertengahan abad ke-17 Masehi.

Somasundrum, Charles. The Continent of Ilamuresam (Lemuria) The Birthplace

of The Dravidian Civilization and Reflection on Event, Following its Disappearence.

Reid, Anthony., 1992. Asia Tenggara Dalam Kurun Niaga 1450-1680, Jilid I: Tanah Di Bawah Angin. Jakarta: Yayasan Obor Indonesia.

- 1999. Dari Ekspansi Hingga Krisis II. Jaringan Perdagangan Global Asia Tenggara 1450-1680. Jakarta: Yayasan Obor Indonesia.

Sismanto \& Nau, N. . F., 2009. Distribusi Batu Arkelogis dari Candi Palgading di Sinduharjo, Ngaglik, Sleman, Yogyakarta dengan Menggunakan Metode Magnetik. Yogyakarta, Fakultas MIPA.

Tabei, T. et al., 2014. Geodetic and Geomorphic Evaluations of Earthquake Generation Potential of the Northern Sumatran Fault, Indonesia. USA, IOP Conference.

Wheatly, Paul, 1959. Geographical Notes on Some Commodities Involved in Sung

Maritime Trade. JMBRAS; Bambang Budi Utomu, 2012. Indonesia Dalam

Arus Sejarah 